\section{Geochemical and petrological constraints on origin and evolution of young silicic magmatism of Chegem, Elbrus, Tyrnyauz volcanic centers (Greater Caucasus, Russia)}

VASILY D. SHCHERBAKOV ${ }^{1,2}$, ILYA N. BINDEMAN ${ }^{3}$, JÖRN-FREDERIK WOTZLAW ${ }^{4}$ AND VIKTOR M. GAZEEV 5

${ }^{1}$ Lomonosov Moscow State University

${ }^{2}$ Fersman Mineralogical Museum RAS

${ }^{3}$ University of Oregon

${ }^{4}$ ETH Zürich

${ }^{5}$ IGEM RAS

Presenting Author: vasiliy7@gmail.com

Large volume ignimbrites, lavas, and young granites of Pliocene to Pleistocene age are uplifted and exposed in continental collision zone of the Greater Caucasus. The volcanic history of the region includes ignimbrite-forming eruptions associated with Chegem caldera (2.92 Ma) and at Tyrnyauz and those found around Elbrus volcanic center (1.98 Ma and 0.7 Ma) followed by numerous lava of modern Elbrus edifice $[1,2]$. Rock composition varies from rhyolite to andesites. We report the result of petrological, geochemical study of rocks, and $\mathrm{O}$ and $\mathrm{Hf}$ isotopic and $\mathrm{U}-\mathrm{Pb}$ dating of zircon to evaluate on origin and evolution of Caucasus young silicic magmatism.

The entire volcanic rock sequence is characterized by depletion in HSFE ( $\mathrm{Nb}, \mathrm{Ta}, \mathrm{Zr}, \mathrm{Hf}$ ) and enrichment in LILE and some fluid-mobile elements $(\mathrm{Li}, \mathrm{Pb})$ highlighting the intimate relation of young silicic magmatism with supra-subduction magma generation. The prominent geochemical feature is extreme enrichment in $U$ and $T h$ up to 8 and $35 \mathrm{ppm}$ respectively.

Chegem and 1.98 Ma Elbrus ignimbrites are both biotite rhyolites (Bt-Q-San-Pl) and characterized by similar bulk rock composition, mineral composition and assemblage, and close ratios of highly incompatible elements arguing for their origin as a product of evolution long-lived silicic crustal reservoir. At the same time, Elbrus ignimbrite compared to Chegem ones has up to two times higher concentrations of incompatible elements, higher $\delta 18 \mathrm{O}$ and lower $\varepsilon \mathrm{Hf}$ indicating $>50 \%$ assimilation of crust during magma reservoir lifetime.

Tyrnyauz granites and old Elbrus Ignimbrites have similar major- and trace element content and the same age, arguing that older Elbrus ignimbrites likely erupted from modern Tyrnyauz area.

Young 0.7 Ma Elbrus ignimbrite and subsequent lavas are typically Bt-Amp-Opx dacites, their mineral assemblage becomes progressively more mafic, and phenocrysts composition and textures display hybrid origin during mixing with mafic magmas. Their source is being investigated.

The research was supported by RSF grant 19-17-00241.

1 Bindeman et al. (2021) JVGR, 412(9):107173; 2 Lebedev et al. (2010) Geochem. Int. 48: 41.
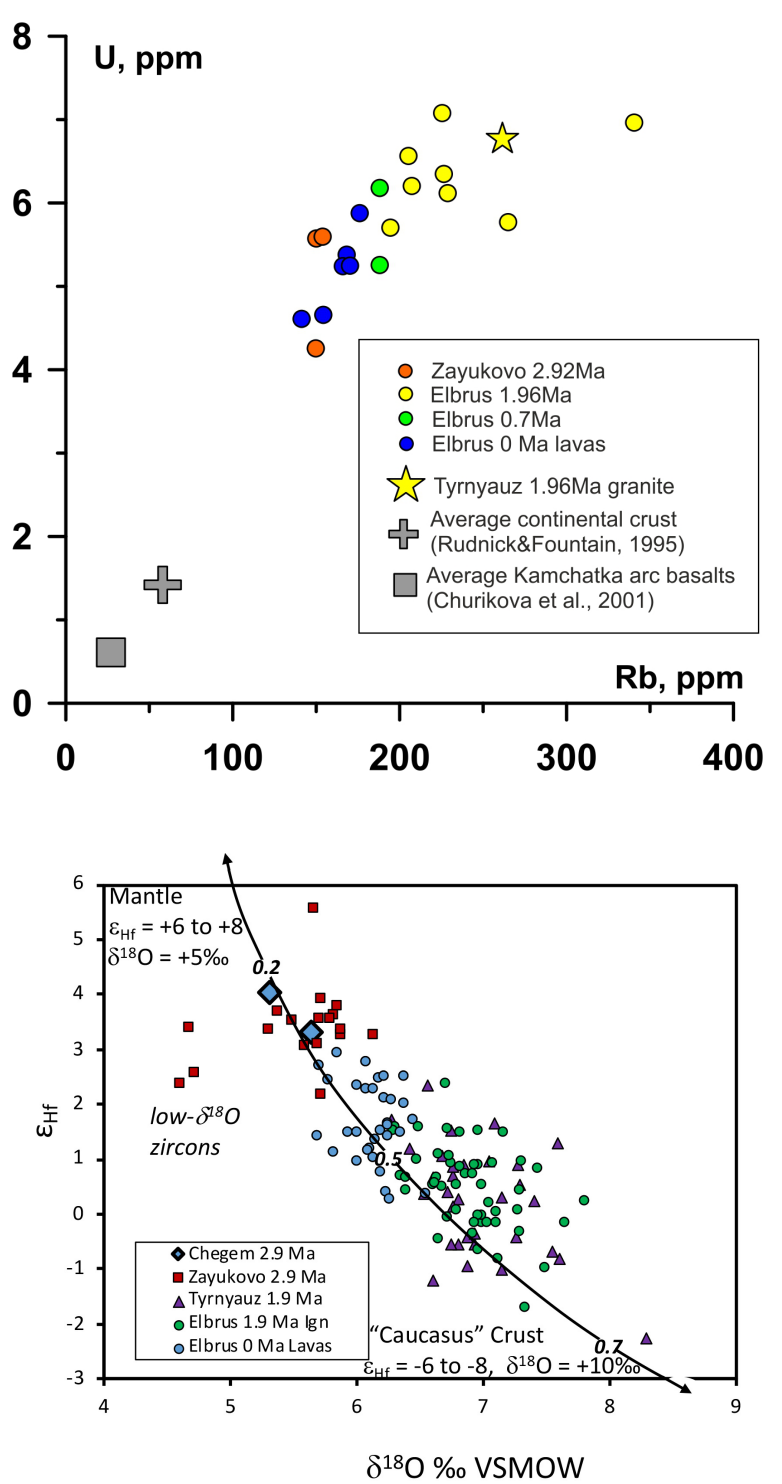